\title{
Characterization of Cells Transformed by Ad5/Ad12 Hybrid Early Region I Plasmids
}

\author{
RENÉ BERNARDS,*† ADA HOUWELING,* PETER I. SCHRIER,* \\ JOHANNES L. BOS,* AND ALEX J. VAN DER EB*,1
}

\begin{abstract}
*Department of Medical Biochemistry, Sylvius Laboratories, Wassenaarseweg 72, 2333 AL Leiden, The Netherlands, and $\uparrow$ Laboratories of Gene Structure and Expression, National Institute for Medical Research, Mill Hill, London NW7 IAA, United Kingdom
\end{abstract}

Received November 30, 1981; accepted April 21, 1982

\begin{abstract}
Early region I (EI) of the human adenoviruses consists of two transcriptional units, EIa and EIb. We have constructed plasmids containing hybrid EI regions from the nononcogenic adenovirus type 5 (Ad5) and the highly oncogenic Ad12. Each plasmid essentially contains the EIa region of one serotype and the EIb region of the other serotype. These hybrid EI plasmids are capable of transforming baby rat kidney cells into cell lines with the typical adenovirus-transformed phenotype, indicating an extensive functional homology between the EI transcriptional units of the two serotypes at the level of transformation. The difference in transformation frequency between the two hybrid EI plasmids suggests that the efficiency of transformation is determined by the identity of the EIa region, i.e., the efficiency is high for clones containing the EIa region of Ad5 and low for clones containing the EIa region of Ad12. In nude mice the Ad5 EIa-Ad12 EIb hybrid-transformed cells show the same high oncogenic potential as Ad12 EI-transformed cells, whereas the Ad12 EIa-Ad5 EIb hybrid-transformed cells express an even lower potential than the Ad5 EI-transformed cells, indicating that the difference in oncogenic potential between Ad5- and Ad12-transformed cells is specified by the EIb region.
\end{abstract}

\section{INTRODUCTION}

The human adenoviruses constitute a heterogeneous group of double-stranded DNA viruses causing acute respiratory infections in their natural host. This group of viruses became the subject of intensive study after the observation of Trentin et al. (1962) that human adenovirus serotype 12 (Ad12) induces malignant tumors following injection into newborn hamsters. Subsequent studies on the oncogenic potential of other human adenoviruses showed that the more than thirty presently identified serotypes can be divided into three subgroups on the basis of this property: subgroup A comprising the highly oncogenic serotypes, subgroup B the weakly oncogenic serotypes, and subgroup $C$ the serotypes that do not manifest any oncogenic activity (Tooze, 1980). The difference in oncogenic potential be-

\footnotetext{
${ }^{1}$ To whom reprint requests should be addressed.
}

tween subgroups $A$ and $C$ is also reflected to a certain extent in the oncogenicity of cells tranformed by viruses of these subgroups, both in syngeneic animals (Mak et al, 1979; Gallimore et al., 1980) and in nude mice (Gallimore et al., 1977; Jochemsen et al., 1982; Van den Elsen et al., 1982). Since rat cells can be transformed into malignant cells by DNA fragments of Ad12 containing no more than the leftmost $16 \%$ of the viral genome (Mak et al, 1979; Jochemsen, 1979; Jochemsen et al., 1982), the difference in oncogenic potential between cells transformed by subgroup $A$ and $C$ adenoviruses is most likely determined by early region I or by one of its subregions, EIa or EIb (Tooze, 1980).

Comparison of the available data on RNA mapping in the EI regions of Ad5 or Ad2 (both subgroup C) and Ad12 (subgroup A) reveals that the structural organization of these regions is essentially the same (Berk and Sharp, 1978; Chow et al., 
1979; 1980; Kitchingman and Westphal, 1980; Perricaudet et al., 1979, 1980a, b; Sawada and Fujinaga, 1980; Bos et al., 1981; Saito et al., 1981). Furthermore, comparison of the nucleotide sequence of the EI regions of Ad5 and Ad12 (Van Ormondt et al., 1980b; Bos et al, 1981) shows that these regions have considerable homology. These findings suggests that the differences in oncogenicity probably must be explained by subtle differences in one or more of the EI gene products. The gene products which are responsible for the oncogenic character of Ad12-transformed cells have not been unambiguously identified as yet. However, BRK cells transformed by the HindIII G fragment of Ad12 (0-7.2\%), which lack the 54-kD major $\mathrm{EIb}$ tumor antigen have lost their oncogenic character in nude mice (Jochemsen et al, 1981; Jochemsen et al., 1982). This implies that the expression of the 54-kD protein somehow is required for oncogenicity. It is not known, however, whether this protein is responsible for the difference in oncogenicity of Ad5- and Ad12 EI-transformed cells. In this paper experiments are reported in which we attempt to elucidate whether this difference resides in the EIa or the EIb region by using two Ad5/Ad12 hybrid EI plasmids: one containing essentially EIa of Ad5 and EIb or Ad12, the other EIa of Ad12 and EIb of Ad5.

It will be shown that both plasmids transform BRK cells into cells with the typical adenovirus-transformed phenotype. Comparison of the oncogenicity in nude mice of BRK cells transformed by these plasmids allows the conclusion that the difference in oncogenicity between Ad5- and Ad12-transformed cells is due to differences in the gene products specified by the EIb regions.

\section{MATERIALS AND METHODS}

\section{Construction of Ad5/Ad12 Hybrid EI Clomes}

1. Construction of clones containing early region $I$ of adenoviruses. The construction of the Ad12 EcoRI C clone (pAd12 RIC) has been described elsewhere (Bos et al.,
1981). To clone the Ad5 SalI B fragment we first removed the residual peptide of the terminal protein from the viral DNA by mild exonuclease III treatment followed by $S_{1}$ nuclease digestion and repairing the termini with DNA polymerase I (Klenow fragment) as described by Bos et al. (1981). After this blunt-ending procedure the viral DNA was cleaved with $\mathrm{SalI}$ and the second largest fragment (0$26 \%$ ) was isolated from an agarose gel following the procedure of Vogelstein and Gillespie (1979). The vector pAT153, a derivative of $\mathrm{pBR} 322$ (Twigg and Sherratt, 1980), was cleaved with HindIII. After phenol extraction and ethanol precipitation the protruiding $5^{\prime}$ ends of the vector were repaired by incubation for $30 \mathrm{~min}$ at $37^{\circ}$ with 50 units $/ \mathrm{ml}$ of Klenow enzyme in the presence of $40 \mu \mathrm{mol}$ of the four dNTPs. After a second cycle of phenol extraction and ethanol precipitation the vector was cleaved with SalI and the large fragment of the vector was recovered from an agarose gel. This fragment was used as vector to clone the SalIB fragment of Ad5: Vector and insert (1:1 molar ratio) were first incubated at $25 \mu \mathrm{g} / \mathrm{ml}$ final concentration for $16 \mathrm{hr}$ at $15^{\circ}$ with $\mathrm{T}_{4} \mathrm{DNA}$ ligase (0.5 unit) and $100 \mu M$ ATP to join the DNA fragments with cohesive ends. ATP was subsequently added to $1 \mathrm{mM}, \mathrm{T}_{4}$ ligase to 5 units, and the ligation was allowed to continue for $6 \mathrm{hr}$ at $37^{\circ}$ to join blunt ends. This DNA was then used to transform $E$. coli HB101. Recombinants were selected from ampicillin-resistant colonies by hybridization selection (Grunstein and $\mathrm{Hog}-$ ness, 1975). Due to the exonuclease III treatment the Ad5 SalI B clone (pAd5 $S a l B$ ) used in the work presented here lacked the left terminal 79 base pairs, as was established by nucleotide sequence analysis (Maxam and Gilbert, 1980). The Ad5 XhoI C fragment (0-15.5\%) was subcloned from pAd5 $\mathrm{SalB}$ by double digesting this plasmid with $X h o I$ and $S a I I$ and subsequent recircularization of the plasmid with T4 DNA ligase.

2. Subcloning of EIa fragments from Ad5 and Ad12 EI clones. 2a. Construction of pAd12 EIa. Fifteen micrograms of pAd12 RIC was cleaved with restriction endo- 
nuclease $A c c I$. After phenol extraction and ethanol precipitation the DNA was repaired by incubation with Klenow enzyme as described above. EcoRI linkers (200 pmol) were ligated onto the repaired $A c c I$ ends following the procedure described by Bos et al. (1981): $1 \mathrm{mM}$ ATP, 5 units T4 ligase, $75 \mu$ l final volume, incubation for $16 \mathrm{hr}$ at $37^{\circ} \mathrm{C}$. After digestion with EcoRI the 1594-base pair left terminal AccI fragment was isolated from an agarose gel. This fragment was then ligated into the EcoRI-cleaved and calf intestine phosphatase-treated vector pAT153.

2b. Construction of $p A d 5$ EIa. Twenty micrograms of pAd5 SalB was cleaved with $H p a I$ and $200 \mathrm{pmol}$ of BamHI linkers was ligated onto the $H p a I$ ends (see section 2a). Half of this DNA was then cleaved with BamHI and EcoRI and the 1572-base pair HpaI E fragment, containing 29 base pairs of plasmid sequence on the left end, was isolated from an agarose gel. This fragment was ligated into the $B a m \mathrm{HI}+E c o$ RI double-digested vector pAT153.

3. Construction of the hybrid EI plasmids. 3a. Construction of pAd125. Ten micrograms of HpaI-cleaved, BamHI-linked pAd5 SalB (see section 2b) was cleaved with $X h o I$ and BamHI. The fragments were separated by agarose gel electrophoresis and the $H p a \mathrm{I}-X h o \mathrm{I}$ fragment mapping between nucleotide 1572 and 5789 was isolated. pAd12 EIa was double digested with $B a m \mathrm{HI}$ and SalI and treated with calf intestine phosphatase. This clone could then be used as a vector to clone the $\mathrm{Hpa}$ $X h o I$ fragment of Ad5 since the $H p a I$ end contains a $B a m H I$ linker and the XhoI end has the same 5'-TCGA-3' overlap as the SalI site of the vector.

3b. Construction of pAd512. Twenty micrograms of pAd12 RIC was partially digested with 3 units of Sau3A for 30 min at $37^{\circ}$. After phenol extraction and ethanol precipitation the DNA was cleaved with RruI and BamHI. After agarose gel electrophoresis the $4.5-\mathrm{kb} S a u 3 \mathrm{~A} / \mathrm{BamHI}$ fragment mapping between nucleotide 1344 of the Ad12 sequence and the BamHI site in the plasmid, was isolated. This fragment was then ligated into the BamHIcleaved and phosphatase-treated vector
pAd5 EIa. After transfection into $E$. coli HB101, tetracycline-resistant colonies were selected. This allows insertion of the Ad12 fragment in a single orientation only as indicated in Fig. 1C.

\section{Cells, Viruses, and DNAs}

Human adenovirus type 5 (strain "Adenoid 75") was propagated in monolayer cultures of $\mathrm{KB}$ cells. Infected cultures (m.o.i. 5-10 PFU/cell) were incubated in MEM $+2 \%$ horse serum for $48 \mathrm{hr}$. Purification of the virus and isolation of viral DNA has been described previously (Van der Eb et al., 1969).

Primary cultures of baby rat kidney cells were prepared from the kidneys of one-week-old WAG-RIJ rats, an inbred rat strain. Transformation of these cells with recombinant plasmids was performed as described by Van der $\mathrm{Eb}$ and Graham (1980).

Cell labeling with $\left[{ }^{35} \mathrm{~S}\right]$ methionine and subsequent immunoprecipitation were performed as described previously (Schrier et al., 1979) with minor modifications. After labeling, the cells were scraped off in a small volume of IPB $(20 \mathrm{mM}$ triethanolamine- $\mathrm{HCl}, \mathrm{pH} 8.0,0.14 \mathrm{M} \mathrm{NaCl}, 0.5 \%$ NP40, $0.2 \%$ DOC, $1 \mathrm{~m} M$ PMSF, $0.1 \%$ trypsin inhibitor). After freezing and thawing, the lysate was centrifuged and the sodium chloride concentration raised to $0.7 \mathrm{M}$. The lysate was precleared extensively with a preformed complex of normal rabbit serum and Staphylococcus aureus bacteria. After immunoprecipitation with anti- $\mathrm{T}$ serum, the samples were analyzed on a $10-15 \%$ SDS-polyacrylamide gradient gel.

\section{S1 Nuclease Analysis}

Total cytoplasmic RNA was hybridized to $3^{\prime}$ end-labeled DNA fragments in $15 \mu \mathrm{l}$ $80 \%$ formamide, $40 \mathrm{~m} M$ Pipes ( $\mathrm{pH} 6.4$ ), 1 $\mathrm{m} M$ EDTA, and $0.4 M \mathrm{NaCl}$ at $53^{\circ}$ for 16 $\mathrm{hr}$. Hybrids were then incubated for $1 \mathrm{hr}$ at $37^{\circ}$ with 200 units $S_{1}$ nuclease in 200 $\mu$ l of $0.25 M \mathrm{NaCl}, 30 \mathrm{~m} M \mathrm{Na}$ acetate, 1 $\mathrm{mM} \mathrm{ZnSO}_{4}$, and $100 \mu \mathrm{g}$ alkali-denatured salmon sperm DNA. Protected DNA fragments were subsequently run on a $5 \%$ DNA sequence gel (Maxam and Gilbert, 1980). 
A

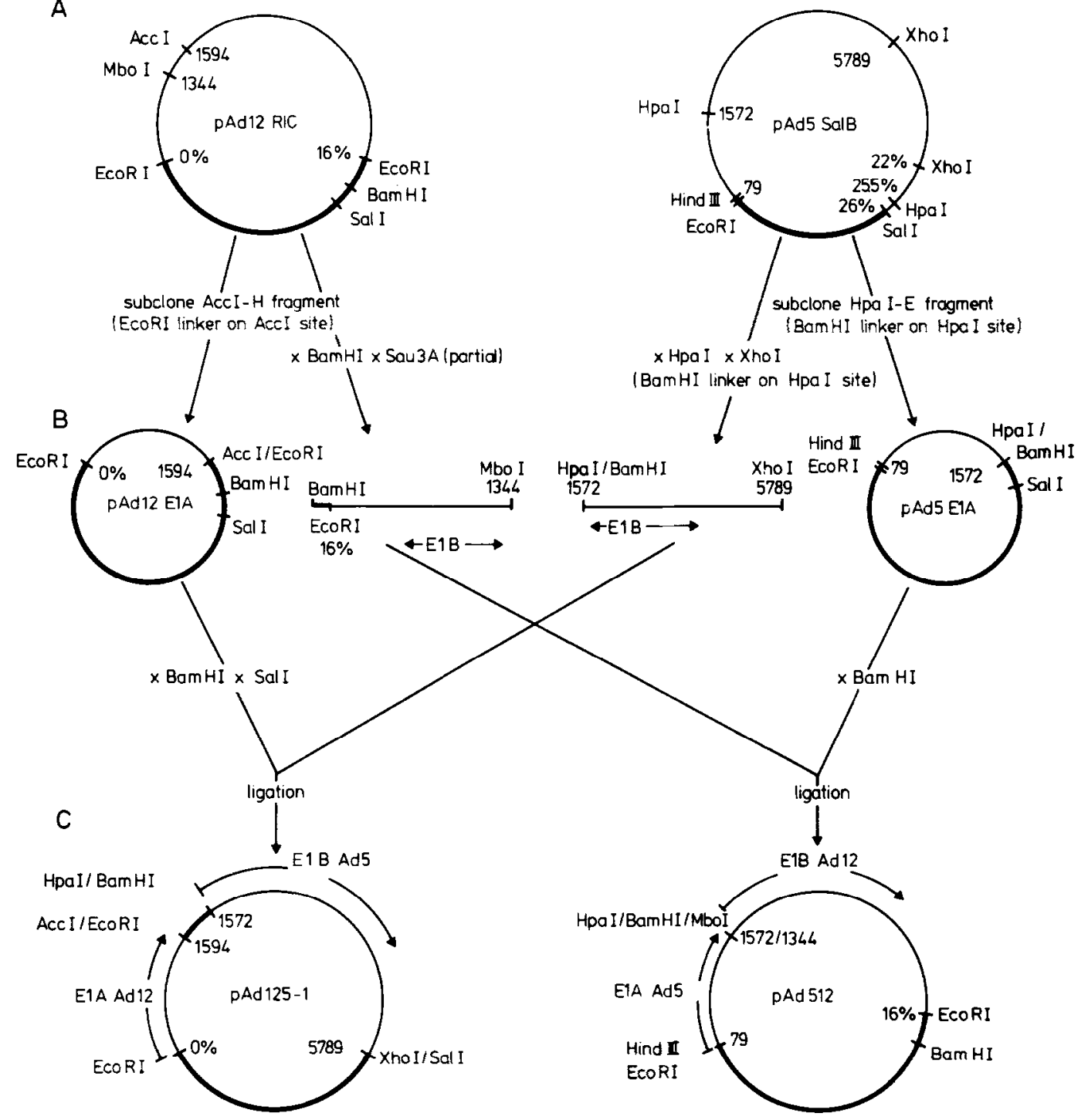

FIG. 1. Construction of Ad5/Ad12 hybrid EI plasmids. The construction of Ad5/Ad12 hybrid EI plasmids is described in detail under Materials and Methods. Thick lines represent plasmid DNA, thin lines viral DNA. Positions of restriction endonuclease cleavage sites in the sequenced areas of the adenovirus genome are indicated by the position of the site relative to the left end of the viral DNA or in map units in the nonsequenced areas. For certain restriction enzymes not all cleavage sites are shown for clarity.

\section{RESULTS}

Construction of Ad5/Ad12 Hybrid EI Plasmids

In order to construct Ad5/Ad12 hybrid EI plasmids the early region I of both Ad5 and Ad12 were cloned in pAT153. The cloning of the Ad12 EcoRI C fragment (0-16\%) has been described elsewhere (Bos et al,
1981). The Ad5 SalI B clone was constructed following a slightly different procedure, omitting the use of synthetic oligonucleotides (see Materials and Methods). From these two EI-containing plasmids fragments were subcloned consisting of the region EIa only (Fig. 1). The plasmids pAd5 Ela and pAd12 EIa (Fig. 1B) were then used as vectors to clone the heter- 
ologous EIb region, yielding pAd512 and pAd125 (Fig. 1C). pAd125 was constructed in two different orientations: one containing the two EI transcriptional units in a head to tail orientation (pAd125-1, Fig. 1C) and the other one containing these segments in head to head orientation (pAd125-2, not shown). The DNA sequence of the essential junctions is consistent with the structure of the hybrid plasmids as presented in Fig. 1C (DNA sequence data not shown). Note that in Ad512 the polyadenylation signal of the EIa region, which is missing on the Ad5 HpaI E fragment (Van Ormondt et al., 1980a; Perricaudet et $a l ., 1979$ ) is supplied by the Ad12 fragment juxtaposed to this Ad5 fragment (Sugisaki et al., 1980; Perricaudet et al, $1980 \mathrm{~b})$. This probably results in an extension of the $3^{\prime}$ untranslated region of the Ad5 EIa mRNAs encoded by this hybrid plasmid with 56 nucleotides.

\section{Transformation of BRK Cells with Hybrid EI Clones}

Primary colonies of pAd5XhoC- and pAd512-transformed cells appeared 10-12 days after transfection, while pAd12 RICand pAd125-transformed cells became visible after 3 to 4 weeks. Cells transformed by pAd512 and pAd125-1 or pAd125-2 exhibited the same polygonal or epithelial morphology as the Ad5 XhoI C- and Ad12 EcoRI C-transformed cells.

The efficiences of focus formation on BRK cells of the hybrid EI plasmids in comparison with pAd12 RIC and pAd5 Xho $C$ are shown in Table 1 . These data show that the transforming activity of pAd512 is in the same order of magnitude as that of pAd5XhoC while both pAd125-1 and pAd125-2 transform with an efficiency comparable to pAd12 RIC. These results suggest that the efficiency of transformation of BRK cells by the hybrid EI plasmids is determined by the identity of the EIa region.

\section{Expression of Viral T Antigens in Hybrid EI-Transformed Cells}

The morphology of the hybrid EI plasmid-transformed cells already suggested that gene products of both transcriptional

\section{TABLE 1}

Transforming activity in Primary Cultures of Baby Rat KIDNEY Cells of Ad5/Ad12 HybRID EARLy Region I Plasmids COMPARED to Ad5 AND Ad12 EI Plasmids

Clone used for Average number of foci/ transformation $\mu \mathrm{g}$ genome equivalent DNA

$\begin{array}{lc}\text { pAd5 Xho } C & 11.6 \\ \text { pAd12 RIC } & 0.55 \\ \text { pAd512 } & 7.6 \\ \text { pAd125 } & 0.42\end{array}$

Note. Subconfluent cultures of primary baby rat kidney cells were transfected with recombinant plasmids (form I) using the calcium technique. Foci were counted 4 weeks after transfection.

units of the hybrid plasmids were expressed. We have verified this by determining the presence and localization of Ad5- or Ad12-specific $\mathrm{T}$ antigen using the indirect immunofluorescence assay. Both types of hybrid-transformed cells show a predominantly nuclear fluorescence (data not shown). The same distribution of $T$ antigen is also found in cells transformed by adenovirus virions or DNA fragments comprising the entire EI region of Ad5 or Ad12 but is quite different from the predominantly cytoplasmic staining pattern observed in cells containing only part of the EI region (Van der Eb et al., 1977; Houweling et al., 1980; Jochemsen et al., 1982). These results show that at least with respect to cell morphology and immunofluorescence staining pattern the EI hybrid-transformed cells exhibit the fully transformed phenotype. This indicates that an extensive functional homology exists between the EI regions of the two serotypes. Furthermore, we have verified the expression of EI genes in the hybridtransformed cells by performing immunoprecipitation using Ad5 or Ad12 anti-T sera and $\left[{ }^{35}\right.$ S $]$ methionine-labeled extracts of hybrid EI plasmid-transformed cells. The same sera were used to immunoprecipitate $\mathrm{T}$ antigens from extracts of pAd5XhoC- or pAd12 RIC-transformed cells as control.

Figure 2 shows that the Ad12 anti-T serum precipitated the two major EIb tumor antigens of 19 and $54 \mathrm{kD}$ from both 




FIG. 2. Polyaerylamide gel electrophoresis of $T$ antigens precipitated from BRK cells transformed by pAd125 (lanes 1-3), pAd512 (lanes 4-6), pAd12 RIC (lanes 7-9), and pAd5 XhoI C (lanes 10-12). Extracts of the cells labeled with $\left.{ }^{35} \mathrm{~S}\right]$ methionine were immunoprecipitated with normal hamster serum (lanes, 1, 4, 7, and 10), Ad5 anti-T serum (lanes, 2, 5, 8, and 11), and Ad12 anti-T serum (lanes 3,6,9, and 12). The positions of the molecular weight marker are indicated.

pAd12 RIC- and pAd512-transformed cells. Similar results were obtained with pAd5 XhoC-transformed cells and pAd125transformed cells using Ad5 anti-T sera. In both cell lines the Ad5 19 and $58 \mathrm{kD}$ major EIb tumor antigens can be detected. The large EIb tumor antigens of Ad5 and Ad12, measuring 54 and $58 \mathrm{kD}$, respectively, are identical to the EIb tumor an- tigens of $60 \mathrm{kD}(\mathrm{Ad} 12)$ and $65 \mathrm{kD}(\mathrm{Ad} 5)$ described previously by us (Schrier et al., 1979; Jochemsen et al, 1980). The differences in apparent molecular weights are explained by the different gel systems used.

The rate of synthesis of EIb $\mathrm{T}$ antigens in the hybrid EI plasmid-transformed cells appeared to be of the same order of 
magnitude as that in Ad5 or Ad12 EItransformed cells, as estimated from the amount of radioactivity precipitated with an anti- $\mathrm{T}$ serum out of $10 \mu \mathrm{Ci}$ of ${ }^{35} \mathrm{~S}$-labeled cell extract.

Since EIa proteins appear only very weakly antigenic it is not possible to test for expression of the EIa region by immunoprecipitation techniques. Therefore $\mathrm{S}_{1}$ nuclease RNA mapping was used to probe for the expression of the EIa region in the hybrid-transformed cells. Total cytoplasmic RNA from the two types of hybrid-transformed cells was hybridized to either Ad5 or Ad12 3 ' end-labeled DNA fragments derived from the EIa region. RNA from pAd5XhoC- and pAd12 RICtransformed cells was used as control. After $S_{1}$ nuclease treatment of the RNADNA hybrids the protected segments were separated on a denaturing $5 \%$ polyacrylamide-urea gel. In this way it is possible to map the $5^{\prime}$ splice sites of the adenovirus EIa mRNAs present in the different transformed cells. The outline of the experiment and the results are shown in Fig. 3. Using the 3' end-labeled Ad5 EIa probe, segments of 160 and 298 nucleotides could be protected against $S_{1}$ nuclease digestion with RNA from pAd512-transformed cells. This shows that in the pAd512-transformed cells the same Ad5 EIa donor splice sites are used as in pAd5XhoCtransformed cells. Similarly, using the Ad12 EIa probe we could detect $S_{1}$ nuclease-resistant segments of 339 and 432 nucleotides with RNA from both pAd12 RIC-transformed cells and pAd125-transformed cells. These data suggest that in the two types of hybrid-transformed cells the EIa regions are faithfully expressed.

\section{Oncogenicity of Ad5/Ad12 Hybrid-Trans- formed Cells in Nude Mice}

A number of primary colonies of BRK cells transformed by each of the hybrid EI plasmids were isolated and established as cell lines. These lines were tested, together with pAd12 RIC- and pAd5XhoC-transformed cell lines, for their ability to induce tumors in nude mice. The results, presented in Table 2, show that pAd12 RICand pAd512-transformed cells are highly oncogenic in nude mice whereas pAd5 Xho C-transformed cells exhibit a lower oncogenicity with a longer latency period relative to the first mentioned lines. The oncogenicity of pAd125-transformed cells is even lower than that of Ad5 XhoC-transformed cells. Comparison of the oncogenicity of pAd12 RIC- and pAd512-transformed cells shows that the EIa region of Ad12 can be replaced by the EIa region of Ad5 without reduction of the neoplastic growth potential of the cells. If, however, the Ad12 EIb region is replaced by the EIb region of Ad5 the oncogenic potential of the transformed cells is drastically decreased (compare pAd12RIC with pAd125 in Table 2). These data suggest that the differences in oncogenicity in nude mice of these adenovirus-transformed cells is determined by one or more gene products of the EIb region.

\section{DISCUSSION}

To study the factors involved in oncogenic transformation of rodent cells by human adenoviruses we have constructed two Ad5/Ad12 hybrid early region I plasmids: one containing essentially the EIa region of $\mathrm{Ad} 5$ and the $\mathrm{EIb}$ region of $\mathrm{Ad12}$, the other the EIa region of Ad12 and the EIb region of Ad5. These hybrid region EI plasmids can transform baby rat kidney cells into cell lines showing the typical adenovirus-transformed phenotype and nuclear $\mathrm{T}$ antigen staining pattern. Furthermore, immunoprecipitation studies showed that both the large $(54-58 \mathrm{kD})$ and the small $(19 \mathrm{kD}) \mathrm{EIb}$ proteins are present in the cells transformed by the two types of Ad5/Ad12 hybrid plasmids, while S1 nuclease RNA mapping showed that the EIa regions of the hybrid plasmids are faithfully expressed in the transformed cells. These properties are characteristic for cells transformed by the entire EI region of adenovirus and are clearly different from those of cells which are transformed by DNA fragments comprising only part of the EI region. For instance, cells transformed by the left terminal $7 \%$ of the adenovirus genome which thus lack the large EIb tumor antigen, are rather similar to cells transformed by the entire 


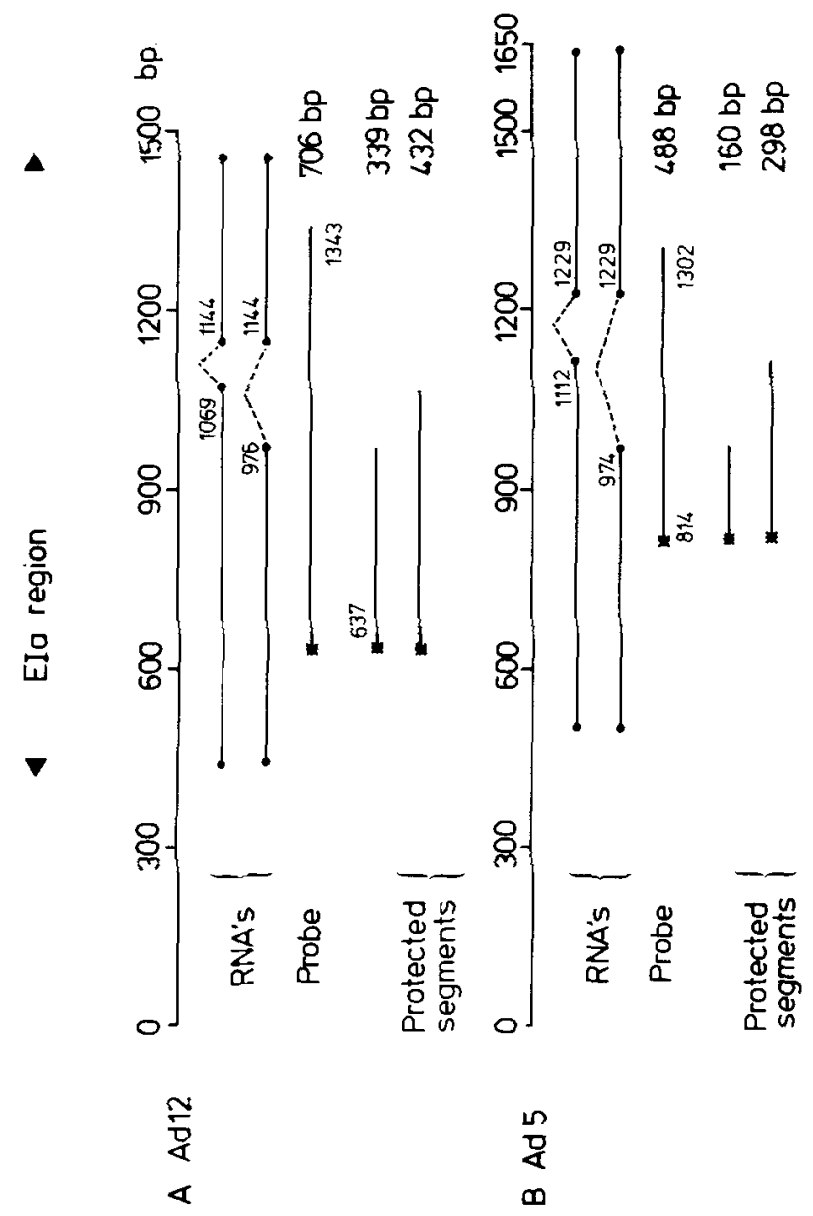

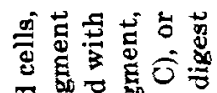

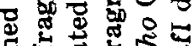

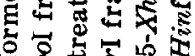

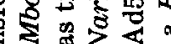

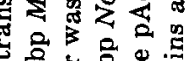

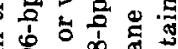

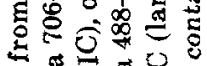

is

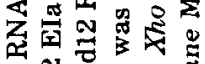

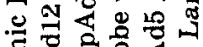

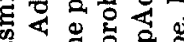

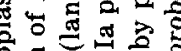

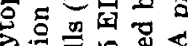

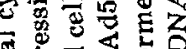

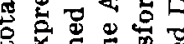

政

证

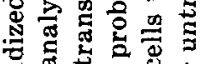

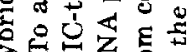

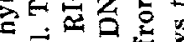

0 品 쿼

3 政通

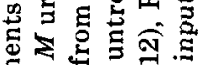

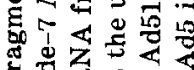

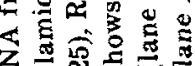

b

둥

형 ส 눈

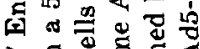
के 5 过

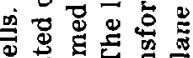

政

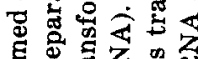

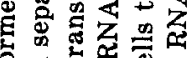

JIY ZLPYd -

$\forall N Y-Z L P \forall-$

indul ZLPY -

jouX SP $\forall d$ -

$\forall N Y-S P \forall-$

indu! SP

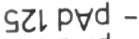

ZIS P $\forall$ d -

w

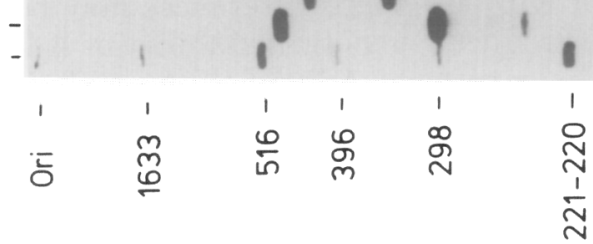

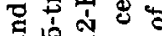

व

월

政

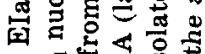

क कि

on 54

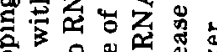

象 8

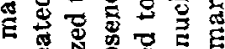

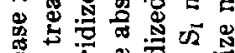

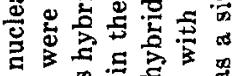
कि क्ष

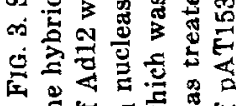


TABLE 2

Tumorigenicity of Baby Rat Kidney Cells Transformed by Ad5-, Ad12-, AND Ad5/Ad12 HybRID Plasmids

\begin{tabular}{ccccc}
\hline $\begin{array}{c}\text { DNA used for } \\
\text { transformation }\end{array}$ & $\begin{array}{c}\text { No. of cells/ } \\
\text { animal }\end{array}$ & $\begin{array}{c}\text { No. of cell } \\
\text { lines tested }\end{array}$ & $\begin{array}{c}\text { No. of animals with tumor } \\
\text { No. of animals injected }\end{array}$ & $\begin{array}{c}\text { Average latent } \\
\text { period (days) }\end{array}$ \\
\hline pAd12 RIC & $10^{7}$ & 6 & $21 / 21$ & $40-50$ \\
pAd5 Xho C & $10^{6}$ & 1 & $2 / 2$ & $45-55$ \\
pAd512 & $10^{7}$ & 9 & $15 / 31$ & $60-80$ \\
pAd125-1 & $10^{7}$ & 7 & $10 / 11$ & $30-40$ \\
pAd125-2 & $10^{6}$ & 3 & $6 / 6$ & $35-45$ \\
\hline
\end{tabular}

Note. $10^{6}$ or $10^{7}$ cells in PBS were injected subcutaneously into 7-week-old homozygous Balb/C nude mice.

region EI with respect to their growth properties and morphology, but they differ in $T$ antigen staining pattern in that the fluorescence is predominantly cytoplasmic rather than nuclear (Van der Eb et al., 1977; Jochemsen et al., 1982). Cells transformed by DNA fragments containing the EIa region only have the same atypical T antigen staining as the $7 \%$ cells, but in addition they differ from the former type by their slow growth rate and fibroblastic morphology (Houweling et al, 1980).

Since DNA fragments comprising the EIb region only have no detectable transforming activity (Houweling et al, 1980; P. J. van den Elsen, unpublished), we conclude that both the EIa and EIb region of Ad5/Ad12 hybrid plasmids are involved in the process of transformation and thus that the regions EIa and EIb of the two serotypes are fully compatible at the level of cell transformation. This implies that the transcriptional units EIa and EIb of Ad5 both contain at least one gene product with a similar biological function in transformation as the corresponding transcriptional unit of Ad12. Recently it was shown that viruses with a lesion in either of the EI transcriptional units can be complemented in lytic infection by wild-type viruses of another subgroup (Brusca and Chinnadurai, 1981; Williams, et al., 1981; Rowe and Graham, 1981), also indicating a close functional relatedness of the EI regions of the adenovirus subgroups.

Our present results also allow us to draw conclusions as to the significance of the previously observed EIa-EIb cotranscripts (Sawada and Fujinaga, 1980). In this study we have used two recombinant plasmids containing the EIa region of Ad12 and the EIb region of Ad5 differing only in the orientation of the EIa region. Since we have found no differences in any of the biological properties of the cells transformed by these two plasmids (i.e., frequency of transformation, cell morphology, immunofluorescence) we conclude that at least in the process of transformation these cotranscripts do not play an essential role.

We have previously observed that adenovirus type 5 transforms BRK cells with higher efficiencies than Ad12 (Jochemsen et al, 1982) and we have suggested that these differences may be due to a greater genetic instability of Ad12 relative to that of Ad5 (cf. Mak et al, 1979). In the work presented here we have found an approximately 20 -fold higher frequency of transformation for Ad5 EI clones relative to Ad12 EI clones. Since four independent isolates of EcoRI C-clones of Ad12 all gave the same low transformation frequency as compared to that of Ad5 we conclude that this is an intrinsic property of the EI re- 
gion of Ad12. Comparison of the transformation frequencies of the two hybrid EI plasmids show that this property segregates with the EIa region. This finding is consistent with our view that the EIa region is involved in the initiation of transformation. This process of initiation of transformation appears to be also dependent on the type of host cell used as evidenced by the fact that Ad5 and Ad12 transform rat embryo brain cells with quite comparable efficiencies (Gallimore and Paraskeva, 1980).

In this paper results are presented of a tumorigenicity assay in nude mice of the Ad5/Ad12 hybrid EI plasmid-transformed cells in comparison with Ad5 and Ad12 EItransformed cells. The tumorigenicity assays in nude mice revealed a high oncogenicity of pAd12 RIC- and pAd512 (Ad5 EIa-Ad12 EIb)-transformed cells, a lower oncongenicity ( $50 \%$ ) of pAd5 Xho C-transformed cells with a prolonged latency period, and a still lower oncogenicity of pAd125 (Ad12 EIa-Ad5 EIb)-transformed cells. This indicates that the difference in oncogenicity between Ad5- and Ad12transformed cells is determined by one or more of the EIb genes. It is tempting to speculate that this difference in oncogenicity is caused by differences between the structure of the large EIb tumor antigens of Ad5 and Ad12, since Ad12-transformed cells lacking this protein are not tumorigenic in nude mice (Jochemsen et al., 1982). However, BRK cells transformed by mutants of Ad12 lacking only the 19-kD EIb tumor antigen are not oncogenic in syngeneic rats either (S. Mak, personal communication) indicating that oncogenicity of transformed cells probably requires the expression of both major EIb tumor antigens. It is therefore not possible at this stage to assign the differences in oncogenic potential to a particular EIb protein. We are currently investigating this matter in more detail by constructing plasmids that allow the expression of the small EIb $\mathrm{T}$ antigen of Ad5 and the large EIb T antigen of Ad12, and reverse.

An important question that remains to be answered is whether the differences in oncogenicity of cells transformed by the
EI region of different adenovirus subgroups are determined by the same factors as those which cause the differences in oncogenicity of intact virions in newborn hamsters. It is likely that the process of in vivo oncogenicity is more complex than oncogenic transformation of rodent cells in vitro, since in the former process factors like differences in permissiveness between Ad5 and Ad12 for hamster cells also play a role. We are presently constructing viruses containing Ad5/Ad12 hybrid EI regions in order to investigate this problem in more detail.

\section{ACKNOWLEDGMENTS}

We thank Dr. R. A. Flavell (National Institute for Medical Research, London) and his group for advice on DNA cloning and support and Ms. M. A. VeerenVink for typing the manuscript.

This work was supported in part by The Netherlands Organization for the Advancement of Pure Research (ZWO) through the Foundation for Fundamental Medical Research (FUNGO) and the Jan Dekker Ludgardine Bouwman Foundation.

\section{REFERENCES}

BERK, A. J., and SHARP, P. A. (1978). Structure of the adenovirus 2 early mRNAs. Cell 14, 695-711.

Bos, J. L., Polder, L. J., Bernards, R., Schrier, P. I., VAN DEN ELSEN, P. J., VAN DER EB, A. J., and VAN ORMONDT, H. (1981). The $2.2 \mathrm{~kb}$ EIb mRNA of human Ad12 and Ad5 codes for two tumor antigens starting at different AUG triplets. Cell 27, 121-131.

Brusca, J. S., and Chinnadurai, G. (1981). Transforming genes among three different oncogenic subgroups of human adenoviruses have similar replicative functions. $J$. Virol. 39, 300-305.

CHOW, L. T., BROKER, T. R., and LEWIS, J. B. (1979). The complex splicing patterns of RNA from the early regions of Ad2. J. Mol. Biol 134, 265-303.

CHOW, L. T., LEWIS, J. B., and BRoKER, T. R. (1980). RNA transcription and splicing at early and intermediate times after adenovirus-2 infection. Cold Spring Harbor Symp. Quant. Biol 44, 401-414.

Gallimore, P. H., MCDOvgall, J. K., and Chen, L. B. (1977) In vitro traits of adenovirus-transformed cell lines and their relevance to tumorigenicity in nude mice. Cell 10, 669-678.

Gallimore, P. H., and Panaskeva (1980). A study to determine the reactions for differences in the tumorigenicity of rat cell lines transformed by Ad2 and Ad12. Cold Spring Harbor Symp. Quant. Bioh 44, 703-713. 
Grunstein, M., and Hogness, D. S. (1975). Colony hybridization: A method for the isolation of cloned DNAs that contain a specific gene. Proc. Nat. Acad. Sci. USA 72, 3961-3965.

Houweling, A., VAN DEN ELSEN, P. J., and VAN DER EB, A. J. (1980). Partial transformation of primary rat cells by the leftmost $4.5 \%$ fragment of adenovirus 5 DNA. Virology 105, 537-550.

Jochemsen, H. (1979). "Studies on the Transforming Genes and Their Products of Human Adenovirus Types 12 and 5." Ph.D. thesis, State University Leiden.

JOCHEMSEN, H., DANIELS, G. S. G., LUPKER, J. H., and VAN DER EB, A. J. (1980). Identification and mapping of the early gene products of adenovirus type 12. Virology 105, 551-563.

JoChemsen, H., DaniëLS, G. S. G., HeRToghS, J. J. L., Schrier, P. I., VAN DEN Elsen, P. J., and VAN DER EB, A. J. (1982). Identification of adenovirus type 12 gene products involved in transformation and oncogenesis. Virology, in press.

Kitchingman, G. R., and WestPhaL, H. (1980). The structure of Ad2 early nuclear and cytoplasmic RNAs. J. Mol Biol. 137, 23-48.

MAK, I., ERVE, H., and MAK, S. (1979). Structure and function of adenovirus type 12 defective virions. $J$. Virol. 32, 240-250.

MaK, S., MaK, I., SmILeY, J. R., and Graham, F. L. (1979). Tumorigenicity and viral gene expression in rat cells transformed by Ad12 virions or by the EcoRI C fragment of Ad12 DNA. Virology 98, 456460.

MaXam, A. M., and Gilbert, W. (1980). Sequencing end-labeled DNA with base-specific chemical cleavages. In "Methods in Enzymology" (L. Grossman and K. Moldave, eds.), Vol. 65, pp. 499-539. Academic Press, New York.

Perricaudet, M., AKuSjärvi, G., Verkanes, A., and PetTersson, U. (1979). Structure of two spliced mRNAs from the transforming region of human subgroup C adenoviruses. Nature (London) 281, 694-696.

Perricaudet, M., Le Moullec, J. M., and PetTersSON, U. (1980a). The predicted structure of two adenovirus T antigens. Proc. Nat. Acad. Sci. USA 77, 3778-3782.

Perricaudet, M., Le Moullec, J. M., Tiollais, P., and PETTERSSON, U. (1980b). Strueture of two adenovirus type 12 transforming polypeptides and their evolutionary implications. Nature (London) 288, 174-176.

Rowe, D. T., and GRahaM, F. L. (1981). Complementation of adenovirus type 5 host range mutants by adenovirus type 12 in coinfected Hela and BHK-21 cells. J. Virol. 38, 191-197.

Saito, I., SATo, J., HaNda, H., SHIRoKI, K., and SHIMOJO, H. (1981). Mapping of RNAs transcribed from adenovirus type 12 early and VA RNA regions. Virology 114, 379-398.

SaWADA, Y., and FuJinaGa, K. (1980). Mapping of adenovirus 12 mRNA transcribed from the transforming region. $J$. Virol. 36, 639-651.

SCHRIER, P. I., VAN DEN ElSEN, P. J., HERTOGHS, J. J. L., and VAN DER EB., A. J. (1979). Characterization of tumor antigens in cells transformed by fragments of adenovirus type 5 DNA. Virology 99 , 372-385.

Sugisaki, H., Sugimoto, K., TAKanami, M., ShIRokI, K., SaIto, I., ShImojo, H., SAWAda, Y., UEmIZU, Y., Ufesugi, S., and Fu.JinaGa, K. (1980). Structure and gene organization in the transforming HindIII $G$ fragment of Ad12. Cell 20, 777-786.

Trentin, J. J., Yale, Y., and TAYLOR, G. (1962). The quest for human cance viruses. Science 137, 835841.

Tooze, J., (1980). "The Molecular Biology of Tumor Viruses," Part 2, "DNA Tumor Viruses," 2nd ed. Cold Spring Harbor Laboratory, Cold Spring Harbor, N. Y.

Twigg, A. J., and SherratT, D. (1980). Trans-complementable copy-number mutants of plasmid Col E1. Nature (London) 283, 216-218.

VAN Den Elsen, P., De Pater, S., Houweling, A., VAN DER VEeR, J., VAN DER EB, A. (1982). The relationship between region EIa and EIb of human adenoviruses in cell transformation. Gene, in press.

VAN DER EB, A. J., VAN KESTEREN, J. W., and VAN BRUGGEN, E. F. J. (1969). Structural properties of adenovirus DNAs. Biochim. Biophys. Acta 182,530541.

Van Der Eb, A. J., Mulder, C., Graham, F. L., and HouwELING, A. (1977). Transformation with specific fragments of adenovirus DNAs. I. Isolation of specific fragments with transforming activity of adenovirus 2 and 5 DNA. Gene 2, 115-132.

VAN DER EB, A. J., and GraHAM, F. L. (1980). Assay of transforming activity or tumor virus DNA. In "Methods in Enzymology" (L. Grossman and K. Moldave, eds.), Vol. 65, pp. 826-839. Academic Press, New York.

VAN ORMONDT, H., MAAT, J., and VAN BEVEREN, C. P. (1980a). The nucleotide sequence of the transforming early region $\mathrm{EI}$ of adenovirus type 5 DNA. Gene 11, 299-309.

VAN ORMONDT, H., MAAT, J., and DIJKEMA, R. (1980b). Comparison of nucleotide sequences of the early EIa regions for subgroup $A, B$ and $C$ of human adenoviruses. Gene 12, 63-76.

VoGelstein, B., and GILlespie, D. (1979). Preparative and analytical purification of DNA from agarose. Proc. Nat. Acad. Sci. USA 76, 615-619.

Williams:, J., Ho, Y. S., and GalOS, R. (1981). Evidence for functional relatedness of products encoded by the transforming sequences of human adenovirus types 5 and 12. Virology 110, 208-212. 